\title{
Influence of Acacia senegal varieties on quality of gum arabic in Baringo District, Kenya
}

\author{
J. K. Lelon ${ }^{1 *}$, I. O. Jumba ${ }^{2}$, J. K. Keter ${ }^{2}$ and F. D. O. Oduor ${ }^{2}$ \\ ${ }^{1}$ Kenya Forestry Research Institute (KEFRI), P. O. Box 20412-00200, Nairobi, Kenya. \\ ${ }^{2}$ University of Nairobi, P. O. Box 30197-00100, Nairobi, Kenya.
}

Accepted April 16, 2013

\begin{abstract}
A study was done to determine the influence of Acacia senegal variety senegal and var.kerensis on quality of gum arabic in Solit, Kapkun, Kimorok and Maoi, Marigat division, Baringo District. Soil and gum arabic samples were collected, dried and analysed to establish their chemical characteristics. Gum nitrogen from $A$. senegal variety senegal in Kapkun and Solit was negatively correlated to soil nitrogen $(r=-0.28)$, while gum nitrogen from variety kerensis at Kimorok and Maoi was positively correlated to soil nitrogen $(r=0.16)$, respectively. High nitrogen content in soils was significantly correlated to high content of nitrogen $(0.30 \%)$ in gum arabic obtained from the $A$. senegal varieties. Gum copper was highly correlated to soil copper $(r=0.09$; $P<0.01)$, soil iron was highly correlated to gum iron $(r=0.09$; $P<0.05)$ and soil manganese and gum manganese was negatively correlated $(r=-0.08 ; P<0.05)$. Gum zinc from $A$. senegal variety kerensis in Kimorok and Maoi was positively correlated to soil zinc $(r=$ 0.53 ; $P<0.05$ ), while gum nitrogen from $A$. senegal variety senegal at Kapkun and Solit was negatively correlated to soil nitrogen and $(r=-0.15)$, respectively. Nitrogen, iron, manganese and zinc contents in gums from $A$. senegal varieties fell within the ranges of the international standard specifications $(0.26$ to $0.39 \% \mathrm{~N}$, iron (730 to $2490 \mathrm{ppm}$ ), manganese (69 to $117 \mathrm{ppm}$ ) and zinc (45 to $111 \mathrm{ppm}$ ), respectively. A. senegal variety senegal in Solit and Kapkun produced better quality of gum arabic than $A$. senegal variety kerensis in Kimorok and Maoi.
\end{abstract}

Key words: Study sites, Acacia senegal varieties, chemical properties, gum quality.

\section{INTRODUCTION}

Acacia senegal (L.) Willd is a leguminous multipurpose tree species, belonging to the subfamily Mimosoideae of the family Leguminosae, found in gum belt of the Sahelian countries of West Africa, which run through the dry woodland forests of Eastern and Southern Africa (Duke, 1981a). Acacia senegal tree produces gum arabic and capable of surviving all but the most severe of droughts in arid and semi-arid environments in subSaharan Africa (Chikamai, 1997). About 90\% of the total gum arabic produced worldwide comes from Acacia senegal, cultivated as a cash crop in agroforestry systems in the Sudan (Duke, 1981a: Keddeman, 1994). Sudan is the major producer and exports more than 80 percent to the world market (Beshai, 1984; Larson and Bromley, 1991; Macrae and Merlin, 2002).

\section{Chemical properties of gum arabic}

Gum arabic is a natural polysaccharide of high-molecular weight, mainly calcium, magnesium, and potassium salts and some mineral elements (Anderson, 1966). It is a 
water soluble polysaccharide of the hydrocolloid group, on hydrolysis yield arabinose, galactose, rhamnose and glucuronic acid. It is a complex mixture of hydrophilic carbohydrate and hydrophobic protein components and comprised mostly of arabinogalactan and protein moiety (FAO, 1990; Williams and Phillips, 2000). Hydrophobic protein component functions as an emulsifier that adsorbs onto surface of oil droplets while hydrophilic carbohydrate component inhibits flocculation and coalescence of molecules through electrostatic and steric repulsions in food additives (Anderson and Weiping, 1990).

The chemical properties of gum arabic quality are critical levels of foreign matter, acid insoluble matter, salts of sodium, calcium, potassium and magnesium, phosphorus nitrogen and protein contents with no tannin content. Mineral contents include copper, iron, manganese, zinc, boron and molybdenum as well as very low levels of arsenic, lead, cobalt, nickel, cadmium and chromium (FAO, 1990). Amino acids are the major constituents of the proteinaceous component of the gum arabic with nitrogen content range of 0.26 to $0.39 \%$ (FAO, 1990).

International specification defines gum arabic as a dried exudate obtained from the stems and branches of A. senegal (L.) Willd. or Acacia seyal from the Sudan (FAO, 1999). Sudan gum sets the international standards on quality and all gum exporting countries must conform well to the standards in all aspects. The international specifications used to assess the quality of gum arabic in the world market are based on the Sudan gum obtained from $A$. senegal variety Senegal.

Gum arabic is used as an emulsifier, binder and stabilizer in the food and pharmaceutical industries (Lelon et al., 2010). Other industrial products that use technical grades of gum arabic include adhesives, textiles, printing, lithography, paints, paper sizing and anti-corrosive coating for metals as well as manufacture of matches and ceramic pottery and pottery glazing (Cossalter, 1991; Idris et al., 1998). Glicksman (1969) has given detailed uses of gum arabic are a function of its physical and chemical properties, as colourless, tasteless, odourless and readily soluble in water, to give aqueous solutions of low viscosity, $\mathrm{pH}$, electrolytes, ageing, compatibility and emulsifying properties. The US Food and Drug Administration, the British Pharmacopoeia and the FAO/WHO Joint Expert Committee on Food Additives (JECFA), have established strict regulations for all food additives which aim to protect the consumer of processed foods containing additives. Gum arabic, like all other food ingredients, is subjected to extensive toxicological research by countries, organizations and users of the produce to ensure the safety of gum arabic from toxicological hazards (Anderson et al., 1990, 1991).

$A$. senegal varieties grow abundantly in areas with annual rainfall of 200 to $800 \mathrm{~mm}$ and high temperatures in the arid and semi-arid lands of Kenya. It plays an important role in restoring the fertility of the degraded soils through biological nitrogen fixation in dryland farming systems. Gum arabic is produced during the dry season in the form of nodules or tear in arid and semiarid lands (ASAL) ecosystem of northern Kenya, namely, Baringo, Isiolo, Samburu, Marsabit, Wajir, Mandera and Turkana (Chikamai and Gachathi, 1994; Chikamai, 1997). The tree produces also other products such as fodder for animals, medicinal products, fibres and fuel-wood (Mocak et al., 1998; Elmqvist, 2003). Gum arabic is collected during the dry seasons by herdsmen and women groups (pastoralists) from natural stands of A.senegal varieties from different botanical sources. The harvested gums are mixed and sold to middle businessmen, usually operating other kinds of trades at local trading centres. These merchants export the gums without standard quality control to world market (Chikamai and Gachathi, 1994).

Kenya has emerged as a new supplier of gum arabic in the world market, but the country does not meet the competitiveness and adequate supply of the commodity to the market (FAO, 1995). Kenya's gum is not able to attract premium prices when compared with the Sudan gum in the world market because of problems relating to quality (FAO, 1990). The international specifications of gum arabic quality specify the optical rotation and nitrogen content as -26 to $-34^{\circ}$ and 0.26 to $0.39 \%$, respectively, (Anderson et al., 1990, 1991). The quality of Kenyan gum has not been investigated adequately to allow its improvement. It has been reported that the quality of gum may be influenced by source or origin, climate, soils and seasons (Chikamai, 1993). Factors needed to be studied that influence quality of gum arabic are climatic and soil conditions, humidity, temperature, altitude and age of the tree, the physiological state of Acacia gum trees, specific variety and seasonal difference, harvest and post-harvest handlings. High quality gum will help to improve production of betterpriced gums locally and internationally (FAO, 1995).

It is believed that gums from different species ( $A$. senegal and $A$. seyal) exhibited characteristics that are intrinsically different, even within the same species, varieties and individual different provenances, which produce gum with different characteristics (Anderson et al., 1968). Recognizing these differences in the species, varieties and environment, it is anticipated that the quality of gum arabic from regenerated natural stands of $A$. senegal may have considerable variation in physicochemical functions and toxicological properties (Chikamai, 1997). Other factors are different locations, type of soil and compositions, specific varieties and habitats, climate, altitude and age of the tree and social factors. To conform to world market requirements, gum arabic for commerce must fulfill certain chemical specifications (Seif el Din and Zarroug, 1996).

Research work on influence of chemical properties of soils on quality of gum arabic from $A$. senegal varieties has not been given adequate attention under dry land environments of Kenya. There is need therefore to 


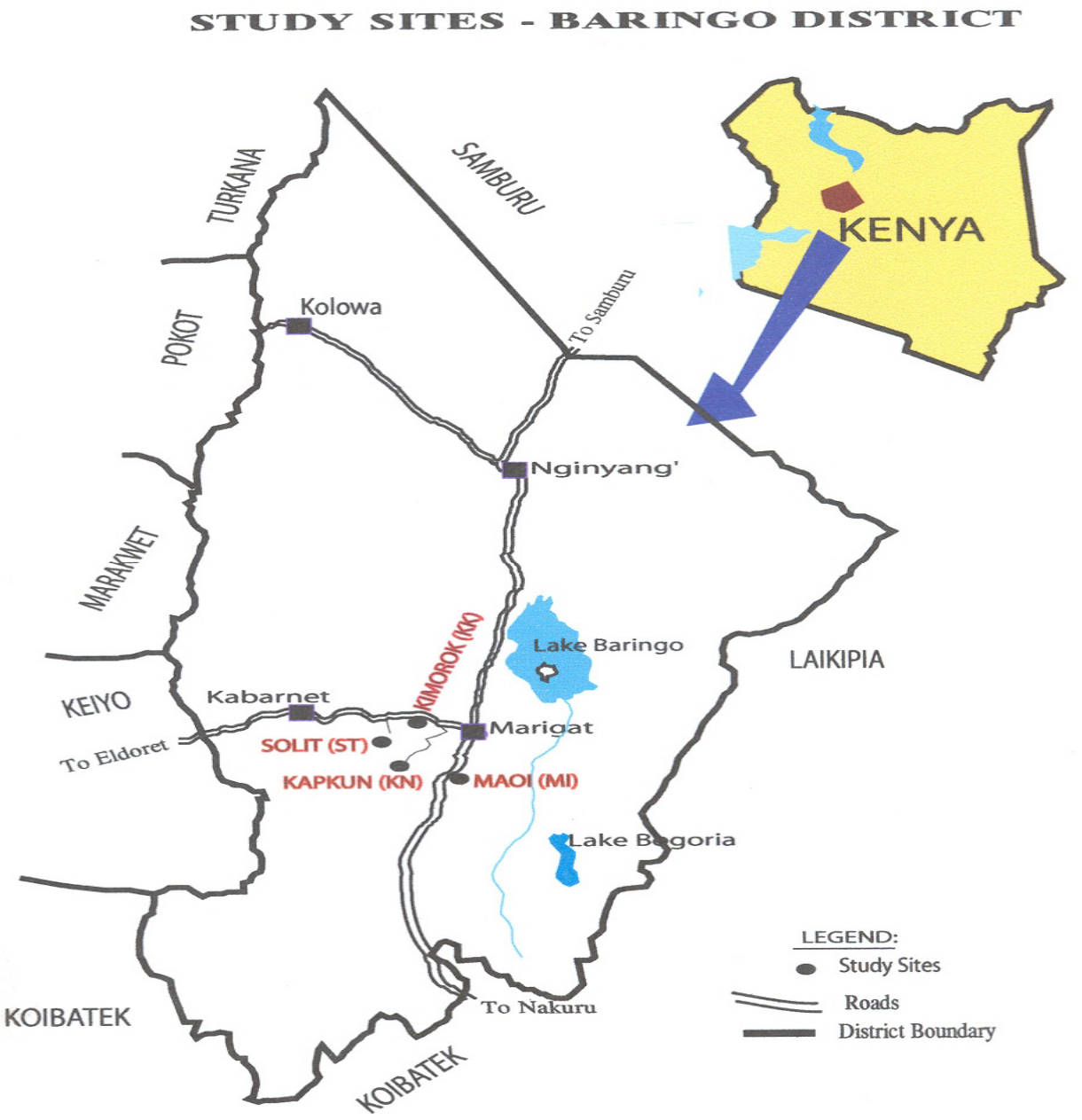

Figure 1. Location of the study sites, Baringo District.

investigate the influence of chemical properties of soils in relation to quality of gum arabic obtained from the natural stands of $A$. senegal varieties between and within sites under the ASAL conditions of Marigat division, Baringo District.

The objectives of this study were to determine the soil chemical properties in relation to chemical properties of gum arabic from $A$. senegal varieties and factors that influence quality in the four study sites and compare the physicochemical characteristics of the gum arabic of the area with international specifications.

\section{MATERIALS AND METHODS}

\section{Study area}

The study sites were Solit (ST), Kimorok (KK), Kapkun (KN) and Maoi (MI) in Marigat division, Baringo District. Baringo District is situated in the Rift Valley region of Kenya and lies between latitudes $0^{\circ} 15^{\prime}$ and $1^{\circ} 45^{\prime} \mathrm{N}$ and longitudes $35^{\circ} 30^{\prime}$ and $36^{\circ} 15^{\prime} \mathrm{E}$ (Figure 1). The district has three main agro ecological zones: lowlands, medium highlands and the highlands (GOK, 1993). The lowlands comprise the northern plateau, Lake Baringo and Kerio Valley basins. This area is predominantly a lowland dry zone which covers about $46 \%$ arid and semi-arid lands (ASALs), with low and erratic rainfall $<500 \mathrm{~mm}$ ), high potential evaporation rates, high temperatures and poor soils (Sombroek et al., 1982). The only activities in Marigat division are livestock, sorghum and millet farming. Selection of study sites was based on survey of high stand density, occurrence and wide distribution of $A$. senegal and its varieties. The size of the plots in Solit and Kapkun with high stand of $A$. senegal var. senegal and other closely related species was 0.5 and 1.0 ha, while 0.8 and 1.0 ha for Kimorok and Maoi with high stand density of $A$. senegal var. kerensis and other closely related species.

\section{Soil and gum arabic analysis}

Soil samples were dug randomly at a depth of 15 to $25 \mathrm{~cm}$ with a mattock, from five different holes and mixed in a basin to give one representative sample in all the four study sites. Thirty samples of about $600 \mathrm{~g}$ each were collected and put in labeled polythene bags. Soil samples were air-dried, ground in a mortar and sieved through $2 \mathrm{~mm}$ sieve mesh to remove gravel for analysis of chemical properties of nitrogen and the trace elements; copper, iron, manganese and zinc. Gum samples were handpicked as nodules 
Table 1. International specifications of quality parameters of gum arabic.

\begin{tabular}{|c|c|c|c|}
\hline \multicolumn{4}{|c|}{ Species: Acacia senegal var. senegal and its varieties } \\
\hline Moisture content $\left(105^{\circ} \mathrm{C}\right)$ & 13 to $15 \%$ & & \\
\hline Ash content $\left(550^{\circ} \mathrm{C}\right)$ & 2 to $4 \%$ & & \\
\hline Volatile matter $\left(105^{\circ} \mathrm{C}\right)$ & 51 to $65 \%$ & & \\
\hline Internal energy $\left(850^{\circ} \mathrm{C}\right)$ & 30 to $39 \%$ & & \\
\hline Optical rotation & -26 to $34^{\circ}$ & & \\
\hline Nitrogen content & 0.26 to $0.39 \%$ & & \\
\hline \multicolumn{4}{|c|}{ Cationic compositions of total ash content $\left(550^{\circ} \mathrm{C}\right)$} \\
\hline Copper & Iron & Manganese & Zinc \\
\hline 52 to $66 \mathrm{ppm}$ & 730 to $2490 \mathrm{ppm}$ & 69 to $117 \mathrm{ppm}$ & 45 to $111 \mathrm{ppm}$ \\
\hline
\end{tabular}

Source of gum arabic: Kordofan Gum Belt Region, Sudan Ref: FAO (1990).

from $A$. senegal variety senegal and variety kerensis. Ninety gum arabic samples of about $200 \mathrm{~g}$ were collected from the four sites during the dry seasons. The samples were air dried for fourteen days and sorted out, cleaned and kept in tight containers and stored at room temperature until analysis. Then, the samples were ground into fine powder to pass $0.4 \mathrm{~mm}$ mesh screen using a pestle and mortar for analysis of nitrogen and the trace elements; copper, iron, manganese and zinc.

Determination of nitrogen contents and trace elements in soil and gum arabic samples

Total nitrogen by Kjeldhal method was determined according to the methods of Anderson and Ingram (1993) and Okalebo et al. (2002). Air-dried soil sample $(0.3 \mathrm{~g})$ was weighed and transferred to labelled clean digestion tubes and $2.5 \mathrm{ml}$ digestion mixture (prepared by dissolving $3.5 \mathrm{~g}$ of selenium powder and $72 \mathrm{~g}$ of salicylic acid in $1 \mathrm{~L}$ of concentrated sulphuric acid) was added, mixed well and placed in a block digester (Skalar Block Digester System, Model SA 5640).

The digestion tubes were heated to $110^{\circ} \mathrm{C}$ for $1 \mathrm{~h}$ and removed to cool for $30 \mathrm{~min}$ before adding three $1 \mathrm{ml}$ aliquots of hydrogen peroxide $(30 \%)$ in succession. The contents were returned to the block digester and heated at $330^{\circ} \mathrm{C}$ for two hours to obtain clear, colourless digests. The contents were removed and allowed to cool, mixed with $25 \mathrm{ml}$ of distilled water and then transferred into a $50 \mathrm{ml}$ volumetric flask and made up to the mark with distilled water. An aliquot of $5 \mathrm{ml}$ solution was transferred to the distillation apparatus and $10 \mathrm{ml}$ of $40 \%$ sodium hydroxide was added. $5 \mathrm{ml}$ of $1 \%$ boric acid and 4 drops of mixed indicator (a reagent used to indicate the end point in a titration procedure) were added to the distillate and then distilled till the indicator turned from red to green. The distillate was titrated with $0.05 \mathrm{M} \mathrm{HCl}$ till the colour changed from green to grey.

\section{Chemical properties of gum arabic}

The methods for determination of nitrogen content and trace elements in gum arabic samples are similar to the methods described in the above nitrogen section according to the methods of Anderson and Ingram (1993) and Okalebo et al. (2002).

\section{Data analysis}

Statistical analysis of data was carried out using SPSS for windows
Release 8.0.0 (1997) and Microsoft Excel (2003) computer software. The statistical method used was Analysis of Variance (ANOVA) using Generalized Linear Models Procedure (GLM).

\section{RESULTS AND DISCUSSION}

\section{Quality of gum arabic}

The international specifications of quality parameters of gum arabic are given in Table 1 . The international specifications state that quality parameters of gum arabic must conform to certain chemical specifications and these must be adhered to by both the producers and processing enterprises (Table 1). The parameters are meant to identify and characterize the toxicological risks and hazards and provide the assurance that gums have not come from other tree species, to maintain and sustain high gum quality in the world market.

\section{Influence of soils on quality of gum arabic}

The chemical properties of soils and chemical properties of gum arabic are given in Table 2. Correlations between soil chemical properties and gum composition in relation to sites and varieties are used to reveal the variety of $A c$. senegal that produce better quality of gum arabic (Table 2). The correlations between soil nitrogen, available micronutrients (copper, iron, manganese and zinc) of soils and gum arabic compositions are presented in Table 3.

\section{Nitrogen}

A. senegal variety senegal in Solit and Kapkun was tested by correlation between soil nitrogen and gum nitrogen $(P<0.05$, Figure 2). The negative correlation between soil nitrogen and gum nitrogen was $r=-0.28$ (Figure 2). This was attributed to high level of SOM $(1.97 \%)$ that increased the availability of nitrogen $(0.3 \%)$ 
Table 2. Chemical properties of soils and gum arabic.

\begin{tabular}{llcccc}
\hline \multirow{2}{*}{ Element } & Site & Solit $(\mathbf{n}=\mathbf{1 7})$ & Kimorok $(\mathbf{n}=\mathbf{1 7})$ & Kapkun $(\mathbf{n}=\mathbf{1 7})$ & Maoi $(\mathbf{n}=\mathbf{1 7})$ \\
\cline { 2 - 6 } & \multicolumn{5}{c}{ Chemical properties of gum arabic } \\
\cline { 2 - 6 } Mean \pm S.E. & Mean \pm S.E. & Mean \pm S.E. & Mean \pm S.E. \\
\hline $\mathrm{N}$ & $\%$ & $0.30 \pm 0.02$ & $0.31 \pm 0.02$ & $0.28 \pm 0.02$ & $0.34 \pm 0.02$ \\
$\mathrm{Cu}$ & $\mathrm{ppm}$ & $39.82 \pm 5.49$ & $38.48 \pm 5.49$ & $45.22 \pm 5.34$ & $32.04 \pm 5.49$ \\
$\mathrm{Fe}$ & $\mathrm{ppm}$ & $973.4 \pm 19.7$ & $1242.6 \pm 19.7$ & $1414.8 \pm 18.7$ & $861.4 \pm 19.7$ \\
$\mathrm{Mn}$ & $\mathrm{ppm}$ & $93.08 \pm 8.76$ & $72.36 \pm 8.76$ & $108.98 \pm 8.52$ & $92.56 \pm 8.76$ \\
$\mathrm{Zn}$ & $\mathrm{ppm}$ & $77.89 \pm 13.6913 .69$ & $123.95 \pm 13.30$ & $82.95 \pm 13.69$ & $43.91 \pm 13.69$ \\
& \multicolumn{5}{c}{ Chemical properties of soils } \\
$\mathrm{N}$ & $\%$ & $0.18 \pm 0.02$ & $0.14 \pm 0.02$ & $0.30 \pm 0.02$ & $0.17 \pm 0.02$ \\
$\mathrm{Cu}$ & $\mathrm{ppm}$ & $1.67 \pm 0.084$ & $0.73 \pm 0.085$ & $0.61 \pm 0.086$ & $0.58 \pm 0.084$ \\
$\mathrm{Fe}$ & $\mathrm{ppm}$ & $151.21 \pm 10.95$ & $233.63 \pm 11.038$ & $250.05 \pm 11.128$ & $287.203 \pm 10.864$ \\
$\mathrm{Mn}$ & $\mathrm{ppm}$ & $263.03 \pm 14.206$ & $319.71 \pm 14.329$ & $343.90 \pm 14.446$ & $383.234 \pm 14.103$ \\
$\mathrm{Zn}$ & $\mathrm{ppm}$ & $1.73 \pm 0.468$ & $7.64 \pm 0.465$ & $6.00 \pm 0.468$ & $5.058 \pm 0.457$ \\
\hline
\end{tabular}

$\mathrm{n}=$ Number of samples analysed; S.E. $=$ standard error.

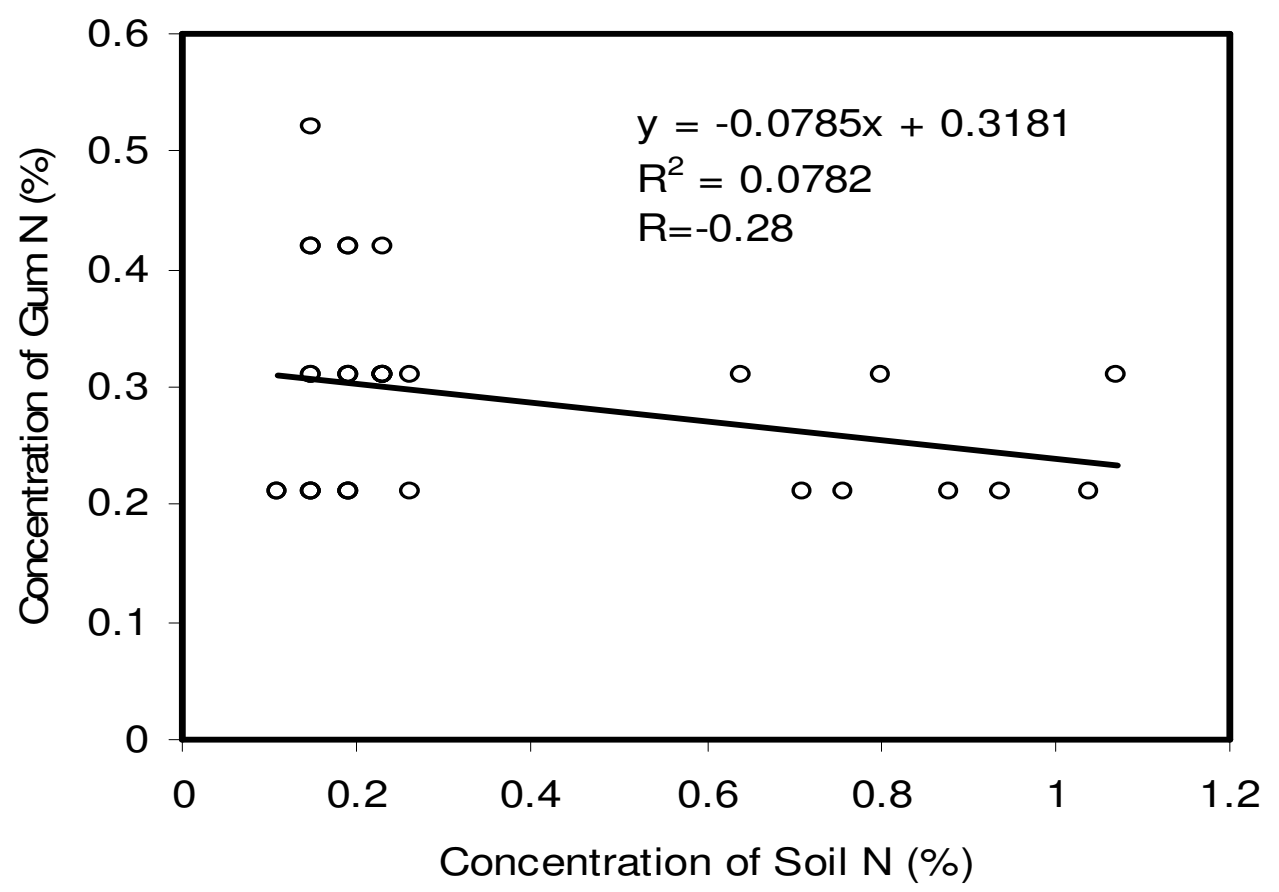

Figure 2. Correlations between soil $\mathrm{N}$ and gum $\mathrm{N}$ in Solit and Kapkun.

in the soils. Soil nitrogen was highly correlated to gum zinc with $r=0.47(P<0.01$, Table 3$)$. The positive correlation showed interaction between nitrogen and zinc as a result of high levels of nitrogen that reduced the availability of zinc uptake by $A$. senegal varieties from the soils (Table 2).

\section{Copper}

The correlation between soil copper and gum copper in
A. senegal variety senegal in Solit and Kapkun was $r=$ 0.088 ( $P<0.05$, Figure 3 ). The positive correlation between soil copper and gum copper in Solit and Kapkun was due to high levels of calcium $(17.33 \mathrm{cmol}(+) / \mathrm{kg})$ that accumulated on the soil surface which reduced the availability of copper uptake by $A$. senegal variety senegal. The correlation between soil copper and gum zinc was $r=0.29(P<0.05$; Table 3$)$. This was attributed to high levels of $\mathrm{Zn}(7.64 \mathrm{ppm})$ that reduced the availability of copper uptake from the soils (Table 2). Gum copper was highly correlated to gum zinc with $r=0.51$ 
Table 3. Correlations between soil and gum chemical properties in sites.

\begin{tabular}{|c|c|c|c|c|c|c|c|c|c|c|}
\hline Correlation & Soil N & Soil $\mathrm{Cu}$ & Soil Fe & Soil Mn & Soil Zn & Gum N & GumCu & Gum Fe & Gum Mn & Gum Zn \\
\hline \multirow{2}{*}{ Soil N } & 1 & -0.079 & -0.017 & 0.037 & $-.390^{\star \star}$ & $-0.244^{\star}$ & 0.13 & 0.166 & 0.232 & $0.465^{\star \star}$ \\
\hline & . & 0.519 & 0.89 & 0.761 & 0.001 & 0.044 & 0.288 & 0.174 & 0.056 & 0 \\
\hline \multirow{2}{*}{ Soil Cu } & -0.079 & 1 & $0.286^{*}$ & $0.333^{\star \star}$ & -0.18 & -0.009 & 0.23 & 0.084 & 0.04 & $0.286^{\star}$ \\
\hline & 0.519 & . & 0.017 & 0.005 & 0.138 & 0.942 & 0.057 & 0.494 & 0.744 & 0.017 \\
\hline \multirow{2}{*}{ Soil Fe } & -0.017 & $0.286^{*}$ & 1 & $0.721^{\star *}$ & -0.143 & -0.018 & 0.18 & -0.133 & $0.321^{\star *}$ & 0.036 \\
\hline & 0.89 & 0.017 & $\cdot$ & 0 & 0.242 & 0.882 & 0.139 & 0.276 & 0.007 & 0.769 \\
\hline \multirow{2}{*}{ Soil Mn } & 0.037 & $0.333^{\star \star}$ & $0.721^{\star *}$ & 1 & -0.231 & 0.059 & 0.011 & -0.038 & 0.117 & 0.06 \\
\hline & 0.761 & 0.005 & 0 & . & 0.056 & 0.63 & 0.928 & 0.756 & & 0.624 \\
\hline \multirow{2}{*}{ Soil Zn } & $-0.390^{\star \star}$ & -0.18 & -0.143 & -0.231 & 1 & -0.06 & $0.289^{\star}$ & -0.167 & 0.091 & 0.108 \\
\hline & 0.001 & 0.138 & 0.242 & 0.056 & . & 0.623 & 0.016 & 0.17 & 0.456 & 0.379 \\
\hline \multirow{2}{*}{ Gum N } & $-0.244^{\star}$ & -0.009 & -0.018 & 0.059 & -0.06 & 1 & -0.204 & 0.082 & $-0.379^{\star \star}$ & -0.225 \\
\hline & 0.044 & 0.942 & 0.882 & 0.63 & 0.623 & & 0.093 & 0.504 & 0.001 & 0.063 \\
\hline \multirow{2}{*}{ Gum Cu } & 0.13 & 0.23 & 0.18 & 0.011 & $0.289^{*}$ & -0.204 & 1 & 0.072 & $0.243^{\star}$ & $0.506^{\star *}$ \\
\hline & 0.288 & 0.057 & 0.139 & 0.928 & 0.016 & 0.093 & . & 0.555 & 0.044 & 0 \\
\hline \multirow{2}{*}{ Gum Fe } & 0.166 & 0.084 & -0.133 & -0.038 & -0.167 & 0.082 & 0.072 & 1 & $-0.447^{\star \star}$ & 0.192 \\
\hline & 0.174 & 0.494 & 0.276 & 0.756 & 0.17 & 0.504 & 0.555 & . & 0 & 0.114 \\
\hline \multirow{2}{*}{ Gum Mn } & 0.232 & 0.04 & $0.321^{\star *}$ & 0.117 & 0.091 & $-.379^{\star \star}$ & $0.243^{\star}$ & $-0.447^{\star \star}$ & 1 & 0.213 \\
\hline & 0.056 & 0.744 & 0.007 & 0.339 & 0.456 & 0.001 & 0.044 & 0 & . & 0.079 \\
\hline \multirow{2}{*}{ Gum Zn } & $0.465^{\star \star}$ & $0.286^{*}$ & 0.036 & 0.06 & 0.108 & -0.225 & $0.506^{\star \star}$ & 0.192 & 0.213 & 1 \\
\hline & 0 & 0.017 & 0.769 & 0.624 & 0.379 & 0.063 & 0 & 0.114 & 0.079 & . \\
\hline $\mathbf{N}$ & 69 & 69 & 69 & 69 & 69 & 69 & 69 & 69 & 69 & 69 \\
\hline
\end{tabular}

$\mathrm{N}=69 ; \mathrm{r}=$ Pearson correlation; $\mathrm{P}$ value = significance $\left(2\right.$-tailed); ${ }^{* *}=$ correlation is significant at the 0.01 level $\left(2\right.$-tailed); ${ }^{*}=\mathrm{correlation}$ is significant at the 0.05 level (2-tailed).

$(P<0.01)$. This may be attributed to high levels of phosphorus that accumulated on the soil surface that reduced the availability of zinc uptake by $A$. senegal varieties from the soils (Table 2 ).

\section{Iron}

The correlation between soil iron and gum iron on $A$. senegal variety senegal in Solit and Kapkun was $r=0.09$ $(P<0.05$, Figure 4). The positive correlation $(r=0.09)$ showed interaction between soil iron and gum iron composition was as a result of the effect of high level of calcium that inhibited concentrations of iron (151.21 and $250.05 \mathrm{ppm}$ ) that reduced the availability of iron uptake from the soils (Table 2). Soil iron was highly correlated to gum manganese with $r=0.32(P<0.01$, Table 3$)$. This was attributed to high levels of manganese (383.23 ppm) that reduced the availability of iron uptake from the soils. Gum iron was highly correlated to gum manganese with $r$ $=-0.45(P<0.01)$. This was as a result of high levels of copper $(1.67 \mathrm{ppm})$ that reduced the availability of iron uptake from the soils (Table 3 ).

\section{Manganese}

The correlation between soil manganese and gum manganese in Solit and Kapkun was $r=-0.08(P<0.05$, Figure 5). The negative correlation in Solit showed interaction between manganese and manganese in gum composition because of the effect of high level of calcium that inhibited concentrations of manganese (263.03 ppm) that reduced the availability manganese uptake (Table 2 ). In Kapkun, available manganese (343.90 ppm) was high because of acidic sandy clay soils ( $\mathrm{pH}$ 5.96).

\section{Zinc}

In Solit and Kapkun, negative correlations between soil zinc and gum zinc was $r=-0.15(P<0.05$, Figure 6$)$. The negative correlation in Kapkun indicated interaction between soil zinc and gum zinc because of high level of phosphorus (13.91 ppm). Solit had high soil $\mathrm{pH}$ and calcium $(\mathrm{pH} 7.05$ and $17.33 \mathrm{cmol} /(+) / \mathrm{kg}$ ) that may have reduced the availability of zinc for uptake by $A$. senegal variety senegal from the soils (Table 2). Soil zinc was 


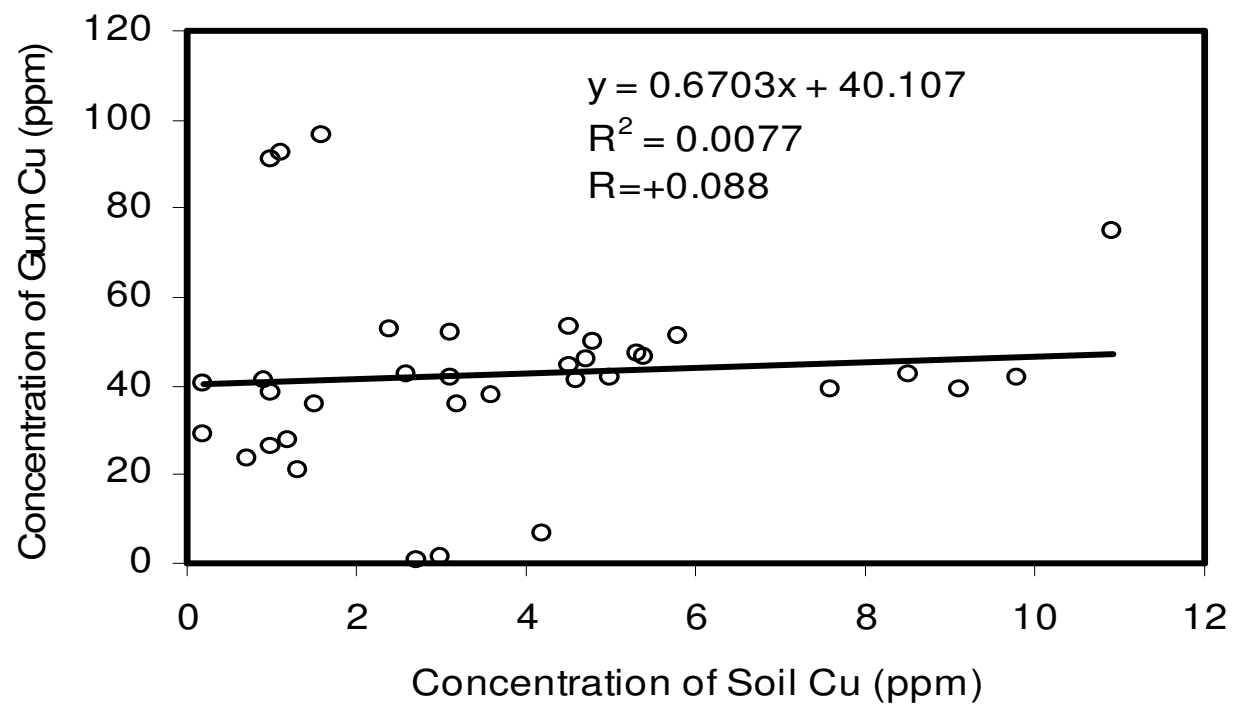

Figure 3. Correlations between soil $\mathrm{Cu}$ and gum $\mathrm{Cu}$ in Solit and Kapkun.

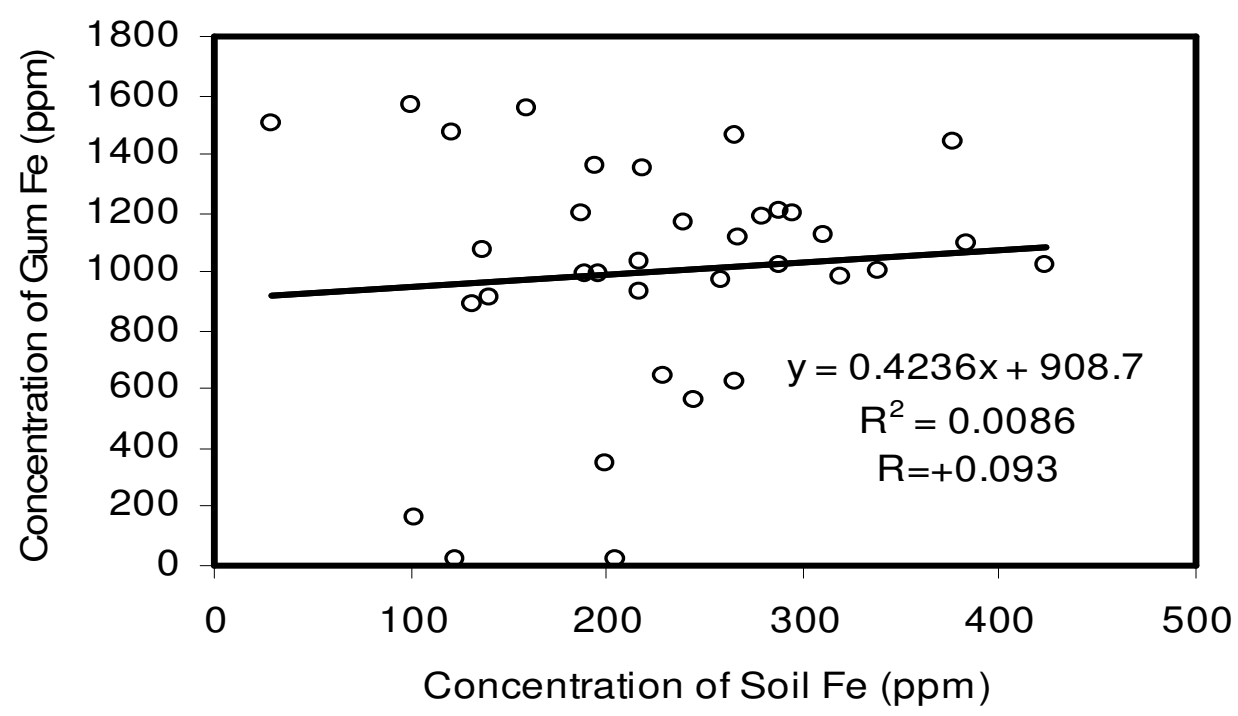

Figure 4. Correlations between soil Fe and gum Fe in Solit and Kapkun.

significantly correlated to gum copper $(r=0.29, P<0.05$; Table 3), because of high levels of iron and manganese (287.20 ppm Fe and 383.23 ppm Mn) which competed with copper ions and reduced its availability in the soil solutions.

\section{Nitrogen}

A. senegal variety kerensis in Kimorok and Maoi was tested by correlation between soil nitrogen and gum nitrogen $(P<0.05$, Figure 7$)$. The positive correlation between soil nitrogen and gum nitrogen was $r=0.16$. This may be attributed to high levels of SOM in Kimorok and Maoi (1.97 and $1.15 \%)$ that increased the availability of nitrogen ( 0.3 and $0.17 \%)$ in the soils (Table 2). Gum nitrogen was highly correlated to gum manganese with $r$ $=-0.38(P<0.01)$. This was attributed to high levels of nitrogen that reduced the availability of zinc for uptake from the soils (Table 2).

\section{Copper}

Correlation between soil copper and gum copper on $A$. senegal variety kerensis in Kimorok and Maoi was $r=$ $0.48(P<0.05$, Figure 8$)$. The correlation between soil copper and gum copper in Kimorok and Maoi were as 


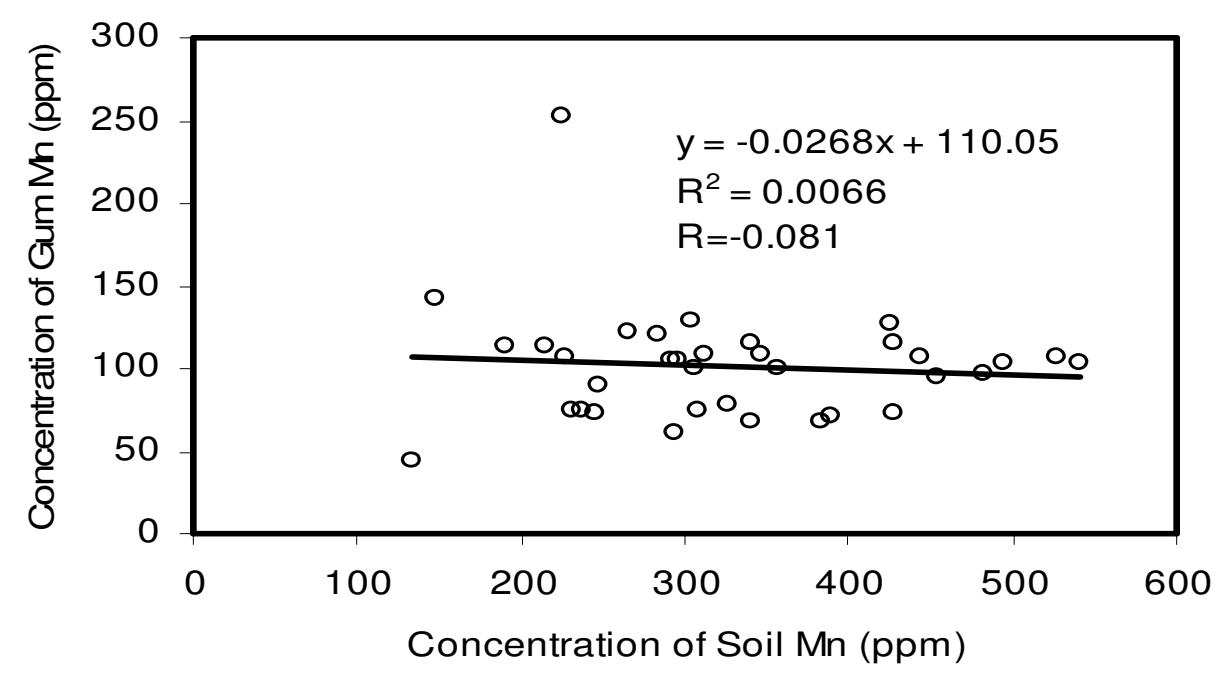

Figure 5. Correlations between soil $\mathrm{Mn}$ and gum $\mathrm{Mn}$ in Solit and Kapkun.

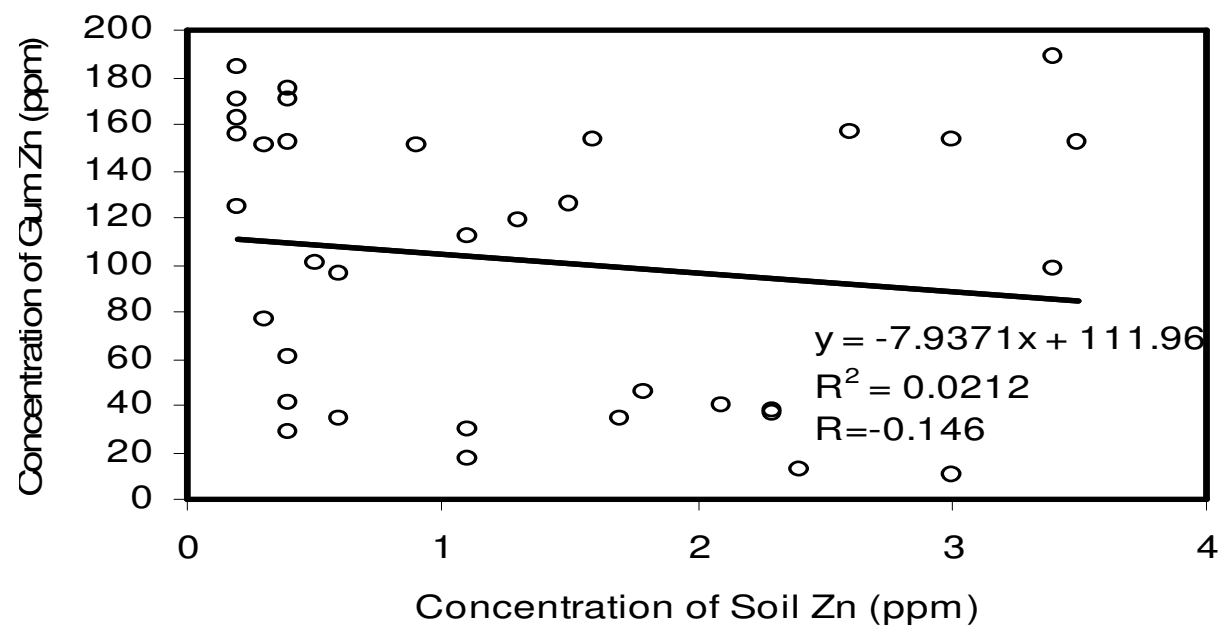

Figure 6. Correlations between soil $\mathrm{Zn}$ and gum $\mathrm{Zn}$ in Solit and Kapkun.

a result of high levels of phosphorus in Kimorok and Maoi (14.6 and $13.90 \mathrm{ppm}$ ) that reduced the availability of copper (0.73 and $0.58 \mathrm{ppm}$ ) in the soils (Table 2).

\section{Iron}

The correlation between soil iron and gum iron in $A$. senegal variety senegal in Kimorok and Maoi was $r=-$ $0.32(P<0.05$, Figure 9). The negative correlation showed interaction between iron and iron in gum composition because of the effect of to high levels of SOM in Kimorok and Maoi (1.97 and 1.15\%) that increased the concentrations of iron (233.63 and 287.20 ppm) uptake from the soils (Table 2).

\section{Manganese}

In Kimorok and Maoi, correlation between soil manganese and gum manganese in $A$. senegal variety kerensis was $r=0.35(P<0.05$, Figure 10). The positive correlations between soil manganese and gum manganese in Kimorok and Maoi were due to the effect of high levels of SOM in Kimorok and Maoi (1.97 and $1.15 \%)$ that increased the availability of manganese uptake from the soils (Table 2).

\section{Zinc}

The correlation between soil zinc and gum zinc in Kimorok and Maoi was $r=0.53(P<0.05$, Figure 11). The positive correlation indicated interaction between soil zinc and gum zinc in Kimorok and Maoi because of high levels of SOM (1.97 and 1.15\%) that increased the availability zinc uptake by $A$. senegal variety kerensis from the soils (Table 2).

These results on correlations between $A$. senegal 


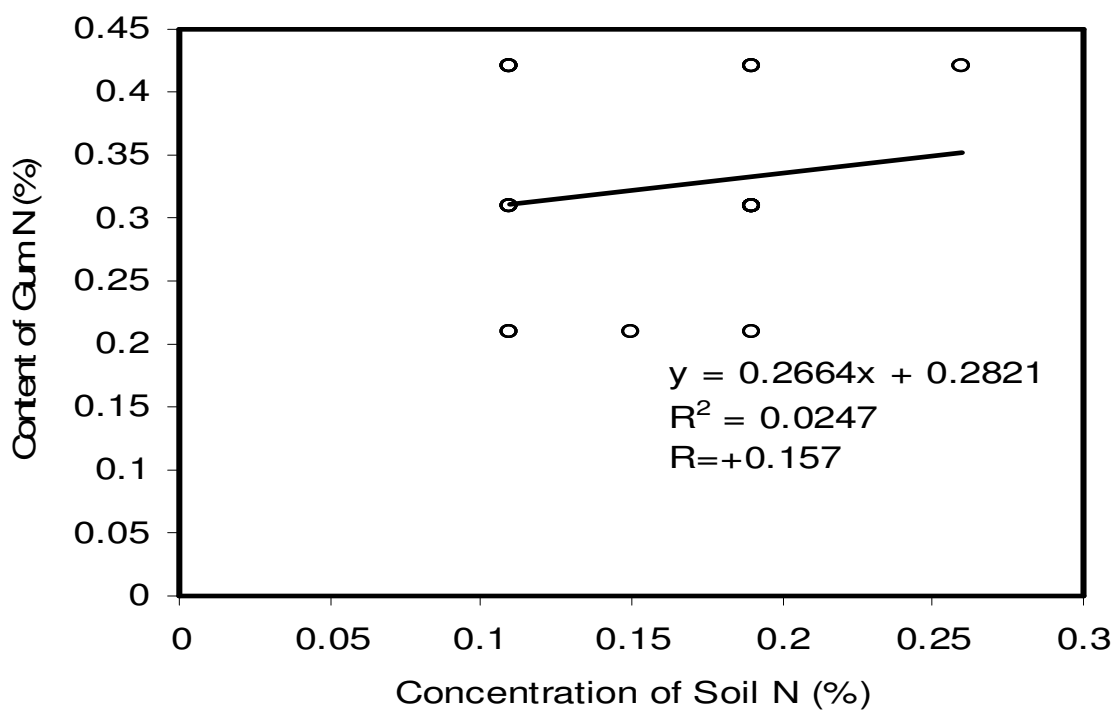

Figure 7. Correlations between soil $\mathrm{N}$ and gum $\mathrm{N}$ in Kimorok and Maoi.

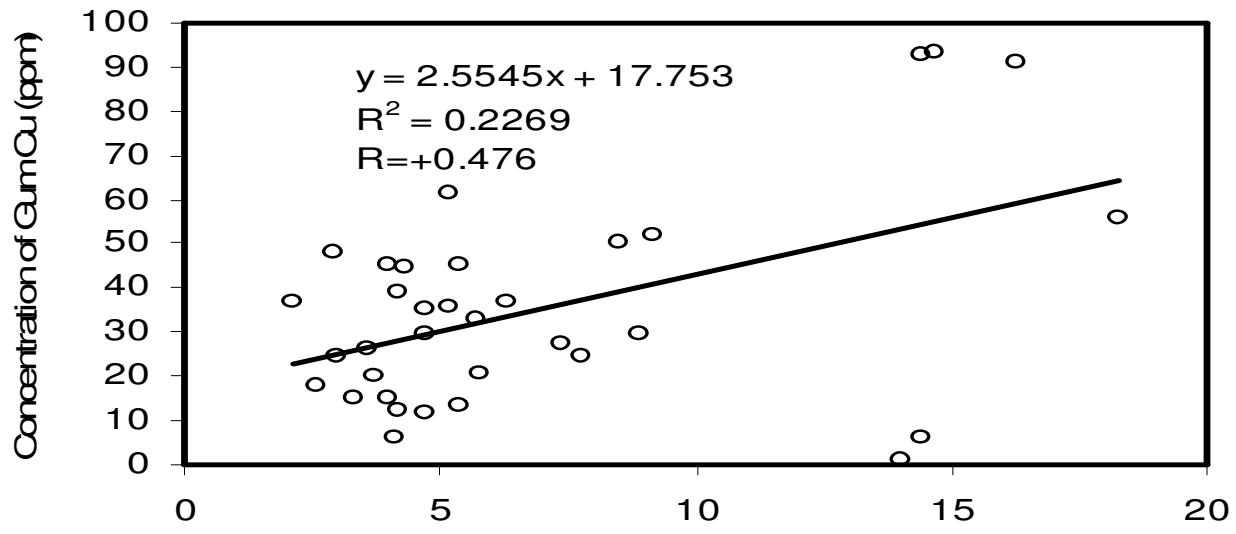

Concentration of Soil Cu (ppm)

Figure 8. Correlations between soil $\mathrm{Cu}$ and gum $\mathrm{Cu}$ in Kimorok and Maoi.

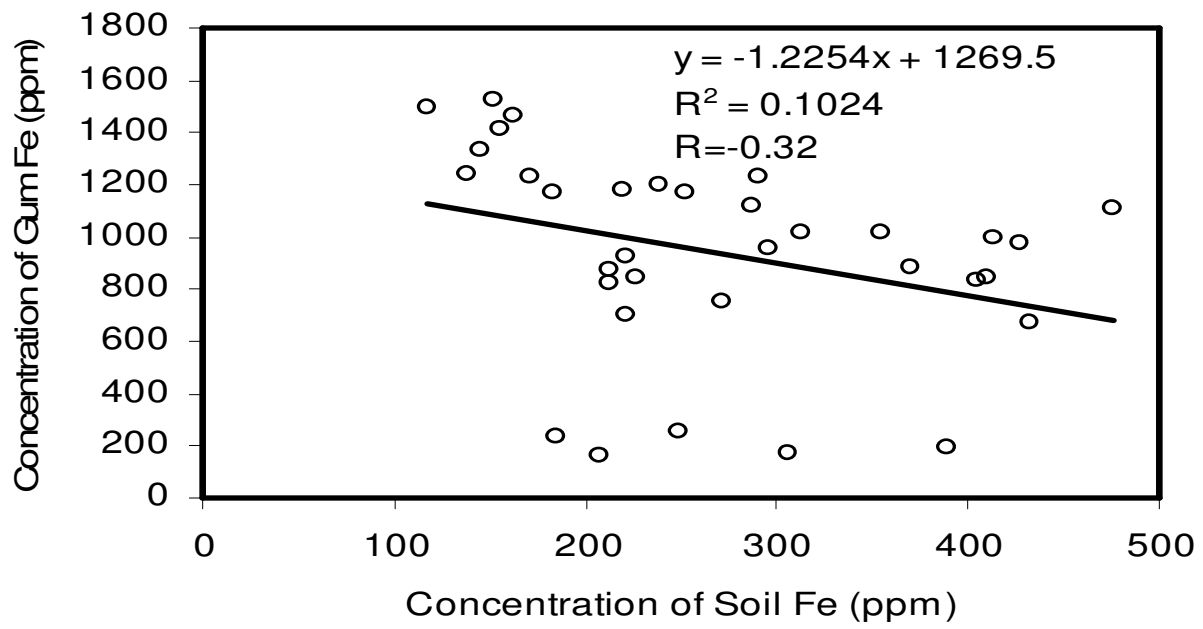

Figure 9. Correlations between soil Fe and gum Fe (ppm) in Kimorok and Maoi. 


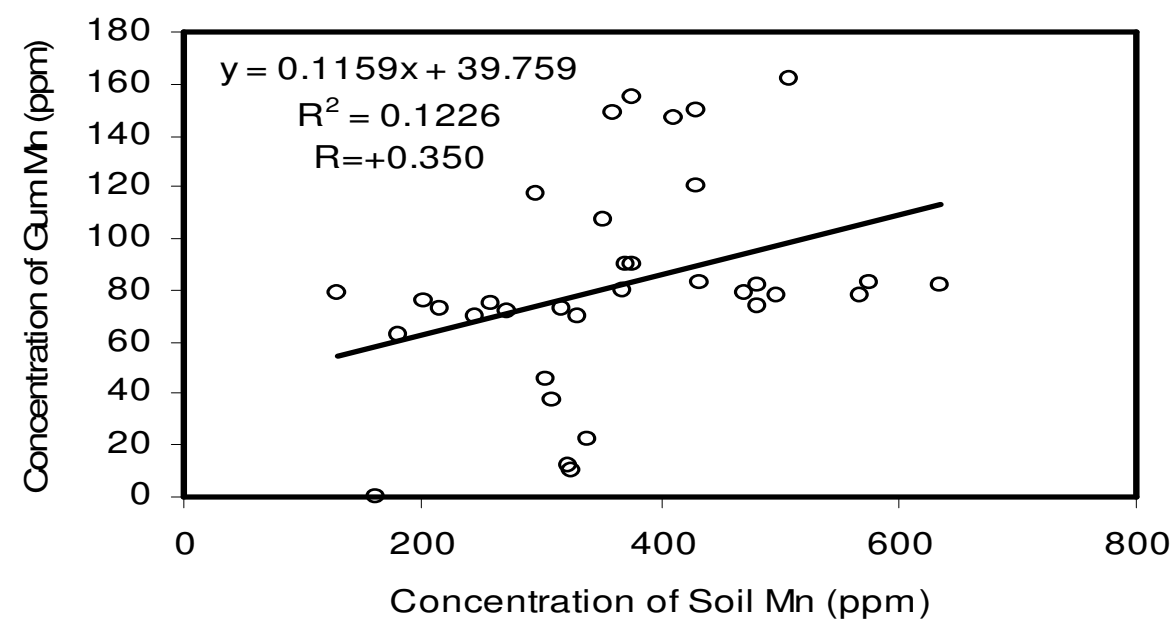

Figure 10. Correlations between soil $\mathrm{Mn}$ and gum $\mathrm{Mn}$ (ppm) in Kimorok and Maoi.

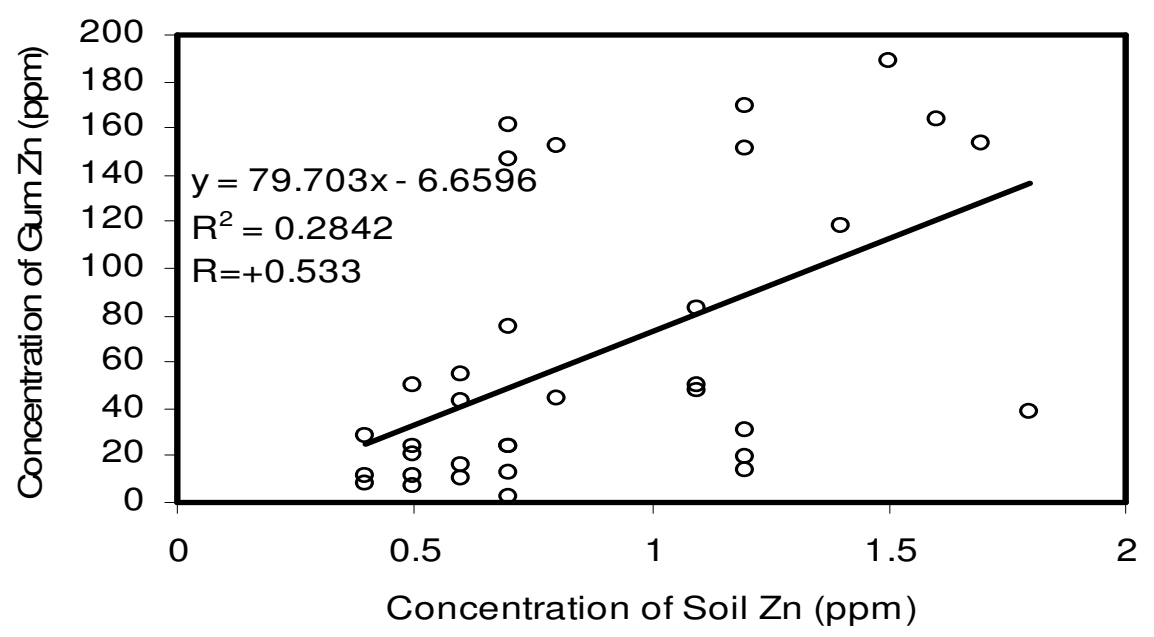

Figure 11. Correlations between soil $\mathrm{Zn}$ and gum $\mathrm{Zn}$ in Kimorok and Maoi.

variety senegal and $A$. senegal variety kerensis on nitrogen content in gum arabic showed that both varieties had the tendency to take high levels of nitrogen from the soils. This was as a result of the ability of the two varieties to fix nitrogen from the atmosphere under natural conditions.

\section{Conclusions}

Quality parameters of gum arabic obtained from $A$. senegal variety senegal were high levels of copper, iron and manganese, while in $A$. senegal variety kerensis, they were high levels of zinc and nitrogen, respectively.

High nitrogen content of $0.17 \%$ in soils of Solit was significantly correlated to high content of nitrogen of $0.30 \%$ in gum arabic obtained from $A$. senegal variety senegal. High nitrogen content of $0.18 \%$ in soils of Maoi was significantly correlated to high content of nitrogen of
$0.34 \%$ in gum arabic from $A$. senegal variety kerensis.

The quality of gum arabic from $A$. senegal variety senegal and $A$. senegal variety kerensis had average nitrogen (0.28 to $0.34 \%)$, and levels of iron, manganese and zinc were similar to gum quality parameters (nitrogen content of 0.26 to $0.39 \%$ ) of international specifications. Gum arabic from Acacia senegal variety senegal had better quality than that of $A$. senegal variety kerensis.

The soil chemical properties (nitrogen, copper, iron, manganese and zinc) showed strong correlations with gum arabic compositions (gum nitrogen, copper, iron, manganese and zinc) which proved the effect of soil conditions as factors influencing quality parameters of gum arabic.

\section{ACKNOWLEDGEMENT}

The authors are grateful to the local communities of 
Kimalel and Kaibosoi locations, Marigat division of Baringo District, for the provision of the four study sites, National Council for Science and Technology for funding the Project and Kenya Agricultural Research InstituteAgricultural Research Fund Secretariat for funding, monitoring and evaluation of the field project sites and Director, Kenya Forestry Research Institute (KEFRI) for provision of laboratory equipment for analysis.

\section{REFERENCES}

Anderson DMW, Brown DDM, Morrison NA, Wang W (1990). Specifications for gum arabic (Acacia senegal) analytical data for samples collected between 1904 and 1989. Food Addit. Contam. 7(3):303-321

Anderson DMW, Millar JRA, Wang W (1991). Gum arabic (Acacia senegal): Unambiguous identification by 13C-NMR spectography as an adjunct to the Revised JECFA Specification and the application of 13C-NMR spectra for regulatory legislative purposes. Food Addit. Contam. 8(4):405-421.

Anderson JM, Ingram JSI (1993). Tropical soil biology and fertility: A handbook of methods. CAB International, Wallingford, UK.

Beshai AA (1984). The economics of a primary commodity: Gum arabic. Oxford Bull. Econ. Stat. 46(4):371-381.

Chikamai BN (1997). "Production, Markets and quality control of Gum arabic in Africa: Findings and Recommendation for FAO Project. In J.O.Mugah, B.N. Chikamai and E. Casadei (eds.)" Conservation, Management and Utilization of Plant Gums, resins and essential oils." Proceedings of a Regional Conference for Africa held in Nairobi, Kenya.

Chikamai BN, Banks WB (1993). "Gum arabic from Acacia senegal (L) Wild. In Kenya. Food Hydrocoll. 7(6):521-534.

Chikamai BN, Gachathi N (1994). "Gum and Resin Resources in Isiolo District, Kenya. Ethnobotanical and Reconnaissance survey". E. Afr. For. J. 59(4):345-351.

Chikamai BN, Odera JA (2002). Commercial Plant Gums and Gum Resins in Kenya. Sources of Alternative Livelihood and Economic Development in the Drylands of Kenya. Executive Printers. NairobiKenya.

Duke JA (1981a). Handbook of legumes of world economic importance. Plenum Press. New York.

Elmqvist B (2003). "The vulnerability of traditional agroforestry systems: A comparison of the gum arabic livelihood strategy before the 1984 drought to that of the present in Kordofan-Sudan". Paper presented on Environment, Place and Sustainable Natural Resource Management Conference. Uppsala, Sweden.
FAO (1997). Food and Nutrition Paper No. 52:5.

FAO (1996). A Review of Production, Markets and Quality Control of Gum Arabic in Africa. FAO, ROME.

FAO (1995). Gums, resins and latexes of plant origin. Non wood forest products Vol. 6.

FAO (1995). The Role of Acacia species in the rural economy of the dry Africa and the near East.

FAO (1990). Food and Nutrition paper, No. 49:23.

Government of Kenya (1993). National Development Plan, Government Printers, Nairobi.

Keddeman W (1994). "Restocking of the gum belt for desertification control in Kordofan, Phase III". Report of the evaluation mission (UNSO/SUD/89/X05). Netherlands Economic Institute, Agricultural and Rural Development Department, Rotterdam.

Larson BA, Bromley DW (1991). "Natural resource prices, export policies and deforestation: The case of Sudan". World-Dev. 19(10):1289-1297.

Lelon JK, Jumba IO, Keter JK, Wekesa C, Oduor FDO (2010). Assessment of physical properties of gum arabic from Acacia senegal varieties in Baringo District, Kenya. Afr. J. Plant Sci. 4(4):9598. ISSN 1996-0824.

Lelon JK, Meshack OM, David W, Odee CW, Beatrice N (2010). Effect of chemical properties of soils on gum elementary compositions from Acacia senegal variety kerensis in Samburu and Marsabit districts. Afr. J. Plant Sci. 4(2):021-025.

Lelon JK (2008). Uptake of Micronutrients by Acacia senegal varieties and its Possible Effect on Gum arabic quality. Ph D Thesis, University of Nairobi.

Macrae J, Merlin G (2002). "The prospects and constraints of development of gum arabic in Sub-Saharan Africa". Washington, D.C., World Bank.

Okalebo JR, Gathua KW, Woomer PL (2002). Laboratory methods of soil and plant analysis: A working manual. Second Edition. TSBFCIAT and SACRED Africa, Nairobi, Kenya.

Sombroek WG, Brawn HMH, Van der Pouw BJA (1982). "The exploratory soil map and agro-climatic zone map of Kenya". Exploratory Soil Survey Report E1. Kenya Soil Survey, Nairobi. 